\title{
What Are Gene Patents and Why Are People Worried about Them?
}

\author{
Jon F. Merz ${ }^{\mathrm{a}}$ Mildred K. Cho ${ }^{\mathrm{b}}$ \\ ${ }^{a}$ Department of Medical Ethics, University of Pennsylvania School of Medicine, Philadelphia, Pa., and \\ ${ }^{\mathrm{b}}$ Stanford Center for Biomedical Ethics, Stanford University, Stanford, Calif., USA
}

\section{Key Words}

Gene patent $\cdot$ Genetic invention · Drug licensing

\begin{abstract}
This article examines what it means to patent a gene. Numerous ethical concerns have been raised about the effects of such patents on clinical medical practice as well as on research and development. We describe what kinds of inventions are covered by human gene patents, give several examples and summarize the small body of empirical research performed in the US examining the effects of these patents. There is little evidence that early fears about gene patenting placing substantial restraints on research and clinical medicine have come to fruition. Nonetheless, there are areas of concern, and policy makers, physicians and the public should be alert to ensure that the net social benefits of patenting human genes are maintained.
\end{abstract}

Copyright $(2005$ S. Karger AG, Basel

\section{Introduction}

Nearly 30,000 human genes have been patented in the US [R. Cook-Degan, pers. commun.]. Patents will often be secured in countries throughout the world where the patent owner thinks there may be a viable market. Patents are granted by the US government to inventors for new, non-obvious and useful inventions and discoveries, and similar standards of patentability are applied around the globe. A patent grants to its owner the right to exclude others from making, using or selling a patented machine or composition of matter, or using a patented method, typically for a period of 20 years from the date of filing a patent application. In contrast to trade secrets (which must be kept secret by their owner and do not protect against independent invention), patents require disclosure that teaches the world how to make and use an invention, rewarding the inventor with a period of exclusivity during which time profits may be earned from its commercialization.

Throughout the developed world, patents are awarded following an examination by a patent agency (e.g., the European Patent Office, the US Patent and Trademark Office). Examination procedures ensure that inventions fulfill the standards for patentability, and that the patent grants protection only for that which has been invented, and no more. The patent claim defines the scope of patent protection. Typically, there is a negotiation between the inventor and the patent examiner, with the former trying to get very broad protections, and the latter seeking to allow a patent narrowly restricted to the technological improvements made by an invention and disclosed in the specification. Broad claims may often be granted for breakthrough inventions, such as those on the polymerase chain reaction (PCR), recombinant technology, gene knock-out methods and even for individual gene sequences. Because

\section{KARGER}

Fax +4161306 1234

E-Mail karger@karger.ch

www.karger.com
(ㄷ) 2005 S. Karger AG, Basel

$1422-2795 / 05 / 0084-0203 \$ 22.00 / 0$

Accessible online at:

www.karger.com/cmg
Jon F. Merz

Department of Medical Ethics, University of Pennsylvania School of Medicine 3401 Market Street, Suite 320

Philadelphia, PA 19104-3308 (USA)

Tel. +1 215573 8107, Fax +1 215573 3036,E-Mail merz@mail.med.upenn.edu 
broad claims to inventions such as a sequence or a recombinant protein are so basic, they cannot easily be invented around, and any improvements are likely to require licenses before they can be used commercially. In biotechnology, such licenses may be impossible to secure, since the owners of the dominant patents are likely to depend upon them to maintain market exclusivity $[1,2]$. In any technology, broad claims will create a disincentive for downstream development and improvements [3].

A patent grants what is called a negative right, i.e., the right to enjoin others from using the claimed invention without permission. A patent owner may turn to the government - through lawsuits for infringement - to use its judicial and police powers to block others from making, using or selling the invention and to collect damages from those who infringe. A patent does not grant its owner the positive right to use an invention, as its use or application may be subject to legal restraints (e.g., human cloning) or regulatory licensing requirements (e.g., drugs and medical devices). Likewise, there is no legal compunction for a patent owner to 'work' or license others to use a patented invention, and, as a general rule, a patent may even be used wholly to keep products from coming to market [4]. Exceptions have been recognized for compulsory licensing of patented inventions when deemed necessary to protect public health and welfare (such as weapons and drugs) [5]. The US Federal Government retains 'marchin' rights to patents resulting from federally funded research if the inventions are not developed for practical application or if necessary to alleviate health or safety needs which are not reasonably satisfied (although this right has never been exercised) [6].

Human gene patents result from the cloning and description of the sequence of a gene, the role or function of which is somewhat understood. As cloning and sequencing capabilities rapidly evolved in the 1980s, patent applications on human genes were filed in increasing numbers. Questions concerning the wisdom of patenting genes were highlighted by the 1991 patent application filed by the US National Institutes of Health that was subsequently amended to cover thousands of expressed sequence tags. Expressed sequence tags are unique nucleotide strings, randomly culled out of the genome, which have no known function other than as a distinctive marker. These applications were ultimately withdrawn, but in 2001, the concerns over the scope of gene patents led the US Patent and Trademark Office to clarify its patentability standard for genes, requiring that a patent applicant make a credible assertion of specific and substantial utility of the genetic invention $[7,8]$.
Gene patents cover three distinct types of invention: (1) diagnostics, (2) compositions of matter and (3) functional uses. We discuss each in turn, providing examples, highlights of areas of concern and what is known about each. This overview is centered on US patent law and what is known about how gene patents are being used in the US. Some of the problems discussed have begun to spill over to Europe, Canada and Australia, as discussed elsewhere in this issue. This is not meant to be a comprehensive international review [9], but only an attempt to demonstrate the breadth of gene patents, discuss concerns about how they are being used and summarize relevant empirical data.

\section{Diagnostic Uses}

The first type of genetic 'invention' covers testing of genetic differences. We have referred to these types of patents as 'disease gene patents', because they claim the characterization of an individual's genetic makeup at a disease-associated locus when performed for the purpose of diagnosis or prognosis [10]. These patents typically cover all known methods of testing, including the use of hybridization, Southern analysis, PCR and even DNA chips. Since the fundamental discovery patented is the statistical observation of a genetic difference and a phenotypic difference (such as the occurrence of disease), then any method for testing for that genetic difference can be covered by the patent [11].

Well-known examples of disease gene patents include those covering genes implicated in breast and ovarian cancers (BRCA1 and BRCA2), colon cancers (HNPCC, FAP), cystic fibrosis (CFTR), hemochromatosis (HFE) and a growing number of neurological diseases including late-onset Alzheimer's disease (Apo-E), Canavan disease, Charcot-Marie-Tooth disease (CMT-1A, CMT-X), spinal muscular atrophy (SMN1), spinocerebellar ataxia (SCA112) and others.

There are several characteristics of genes and disease gene patents that demonstrate how the genome is being divided up by small patent claims to overlapping genetic territory. First, any one gene may have multiple patents claiming the diagnosis of different polymorphisms. Thus, several patents have been issued for testing of different mutations in the CFTR gene [12]. Further, some diseases (at least the phenotypic expressions of them) are caused by multiple genes, such as Charcot-Marie-Tooth disease [13]. Questions about ownership and access get messy when there are many hundreds of known mutations in 
multiple causative genes, as exemplified by BRCA1 and BRCA2, for which there are at least a dozen US patents on tests of these two genes [14]. Finally, patents can issue on the same exact molecular test when it is performed for different diagnostic or prognostic purposes. For example, an Apo-E test, in which the number of E2, E3 and E4 alleles carried by a patient is assessed, can be performed for each of the following patented uses: (1) determining whether a patient is at risk of early onset Alzheimer's disease [15]; (2) assessing an Alzheimer's disease patient's prognosis [16]; (3) determining a course of therapy based on pharmacogenetic receptivity [17], and (4) assessing a patient's prostate cancer risk [18]. Apo-E is also used for the assessment of cardiovascular risk, but this use has not been patented. In these cases, a patent thicket is created that can lead to difficulties in securing licenses and expenses in paying multiple 'stacked' royalties to multiple patent owners [19].

To the best of our knowledge, the owners of the overwhelming majority of issued gene patents have not aggressively enforced their rights against clinical molecular diagnostics laboratories. Nonetheless, a majority of genetics laboratories across the US report that they have had one or more of the above disease gene patents asserted against them [20,21]. In some cases, these patent owners have been willing to grant a license to laboratories performing a home-brew test. Per test royalties of which we have become aware include USD 2 for the $\Delta$ F508 mutation of CFTR (University of Michigan), USD 5 for Gaucher's disease (Scripps Institute), USD 12.50 for Canavan disease (Miami Children's Hospital) and reportedly more than USD 20 for HFE (Bio-Rad). In some cases, an up-front license fee (not tied to volume) has been demanded as well [22]. While these royalties arguably reduce access and create problems for laboratories, they must be examined in the context of the US commercial, profit-centered health care system.

Clinical as well as research laboratories typically pay royalties for the use of patented technologies. For example, the price of widely-used PCR machines and reagents includes a premium paid for the use of the patented technologies. In addition, a royalty of about $9 \%$ is paid for all testing done by licensed laboratories [21]. As discussed in great detail by Nicol [23], the most recent patents enforced against biotechnology companies and testing laboratories are those that claim the extremely broad uses of intronic and extra-gene sequences for generating haplotypes and identifying allelic variation [24]. Disease gene patents vary in significant ways from these more typical patented tools that are used by laboratories for testing for a variety of specific disease genes. Critically, since a disease gene patent claims all methods of testing for a specific gene, there is no plausible way of working around these patents and the patents may be used to monopolize a test.

Fortunately, in only a handful of cases, patent owners have refused to grant licenses to laboratories to allow them to perform specific tests. In a few cases, patent owners have used the patents to monopolize the testing service, requiring physicians and laboratories to send samples for testing to the owner or its specified licensees. Thus, tests for breast and ovarian cancer genes (Myriad Genetics) and a set of neurological disorders (Athena Diagnostics) are generally available from only these commercial laboratories. SmithKline Beecham Clinical Laboratories made a brief attempt at capturing the testing market for hemochromatosis before the business unit was sold to Quest Diagnostics, which then transferred ownership to Bio-Rad [22]. Myriad has extended its reach beyond the US borders, seeking to enforce its BRCA patents in, amongst others, France [25], Canada [26] and the UK [27]. The test for Canavan disease, despite being easily included in panel assays that many laboratories can run, was restricted to selected laboratories around the US by the patent owner, Miami Children's Hospital [28].

In these cases, laboratories have been told where patient samples must be sent to have the patented tests performed and how much it will cost. Being compelled to stop providing testing services has serious implications for the ability of molecular pathologists to maintain currency in their field, to treat their patients with comprehensive medical services, to train residents and fellows, to perform research and to run their laboratories in an efficient manner. Hospital-based laboratories must often absorb part of the fixed monopoly costs of the tests which they are compelled to offer patients but for which health insurance may not cover the full price. Seen in this light, these patents raise the costs of clinical services and restrict physicians' ability to practice medicine [4, 29].

\section{Compositions of Matter}

The second broad type of genetic invention relates to compositions of matter (i.e., chemicals and materials), including the isolated and purified gene (cDNA) and all derivative products (e.g., recombinant proteins or drugs, viral vectors and gene transfer 'therapies', transfected cells, cell lines and higher order animal models in which the patented gene has been inserted or knocked out). According to the Biotechnology Industry Organization, 
there are more than 200 biotechnology drugs and vaccines that have been approved by the US Food and Drug Administration [30], and more than 370 drugs are in clinical trials [31].

Patents on human genetic compositions of matter cover a broad array of chemicals and technologies. For example, human insulin, human growth hormone and many other proteins that can be isolated and purified from human blood or urine can be patented. Further, synthesized products can be covered by various patent claims, including (1) claims to the sequences used (both the sequence to be transcribed into RNA and proteins as well as promoter sequences); (2) the virus or other vectors containing the claimed sequence; (3) transfected cells, cell lines and nonhuman organisms created and used in these processes, and, perhaps most importantly, (4) the proteins or other therapeutic products made by these claimed processes. The last, called 'product by process' claims, allow patent owners to prohibit the use or sale of products made by the claimed processes, regardless of where the product is made.

\section{Functional Use}

Finally, a third and emerging class of gene patents is that which claims the functional use of a gene. These patents are based on discovery of the role genes play in disease or other bodily and cellular functions or pathways, and claim methods and compositions of matter (typically called 'small molecule' drugs) used to up- or downregulate the gene. Note that these drugs are not likely gene products, but rather other types of chemicals found to effect gene functioning, and the drugs are likely patentable themselves as unique chemical entities useful as therapy. For example, a patent that was recently invalidated claimed methods and compositions of matter for the selective inhibition of the Cox-2 gene, which prevents inflammation and pain. The patent was invalidated because the patentee, the University of Rochester, failed to disclose a chemical entity that would perform such selective inhibition [32]. The patent claimed the mechanism by which three drugs that later came to market work: Celebrex, which is co-marketed by Pharmacia (of which Searle is part) and Pfizer, Pfizer's Bextra and Merck's Vioxx. Each one of these chemical entities may be patented as a new, non-obvious and useful drug for the treatment of inflammation and pain, but the Cox-2 patent attempted to claim all drugs that work by manipulating the function of the target gene.
A similar case to the Cox-2 litigation involves a patent awarded to Harvard and Massachusetts Institute of Technology and exclusively licensed to Ariad Pharmaceuticals. The patent claims the basic regulation of any genes by reducing intracellular activity of the transcription factor NF-kB [33]. Upon award of the patent, Ariad sued Eli Lilly for infringement by their osteoporosis drug Evista and their sepsis drug Xigris and has asserted the patent against numerous other companies. Lilly's patent applications for these two compounds predate the filing of the NF-kB application [34]. Ariad should have a hard time winning, both because, like the selective Cox-2 inhibition patent, the NF-kB patent fails to disclose specific agents for regulating the factor and because the company is trying to assert its patent in a way that would remove from the market chemical entities that predated the discovery and disclosure of the functional pathway by which those drugs work.

Finally, we have the case of Viagra. Pfizer, which has had its erectile dysfunction drug Viagra on the market for several years, recently received a patent claiming the molecular pathway by which Viagra works. The patent claims any selective PDE5 inhibitor used to treat impotence [35]. Immediately upon allowance of its patent in late 2002, Pfizer sued Bayer and GlaxoSmithKline for their drug Levitra and Eli Lilly and their partner Icos for their drug Cialis, while both drugs were proceeding towards the Food and Drug Administration approval (and have since been approved) [36]. The difference between the Viagra case and the Cox-2 case is that Pfizer actually has and claims a specific class of drugs that work by the claimed functional pathway. Whether this is an adequate basis on which to allow Pfizer to lay claim to all drugs that work by the same molecular mechanism is a fundamental legal question that looms over the pharmaceutical industry.

\section{Concerns about Gene Patents and Research}

One of the primary concerns about human gene patents is that they will make it more difficult to perform research, thereby delaying or impeding discovery and development of diagnostics and therapeutics [37]. In the US, there is no statutory research exemption, but only an extremely narrow court-defined exemption. As recently summarized by the Court of Appeals for the Federal Circuit in a lawsuit against Duke University, 'regardless of whether a particular institution or entity is engaged in an endeavor for commercial gain, so long as the act is in furtherance of the alleged infringer's legitimate business and 
is not solely for amusement, to satisfy idle curiosity or for strictly philosophical inquiry, the act does not qualify for the very narrow and strictly limited experimental use defense' (italics added) [38]. Duke was not excused from potential infringement of patents covering laboratory equipment simply because the equipment was used solely for research and educational purposes, which the Court found to be the core of Duke's business. A strong argument can be made that the research exemption should be much broader, encompassing research aimed at better understanding of the claimed invention, such as how it works and whether it works as taught by the patent, how to improve upon it and how to work around it. Indeed, practically speaking, this may in fact be how patents are most commonly used. As a colleague stated it, research on the invention should be exempt while research using the invention is infringement [P. Ducor, pers. commun.]. As mentioned earlier, the patent law trades a period of exclusivity for disclosure, and competitors should not have to wait for the period of exclusivity to end before learning from that disclosure and attempting to improve upon it. The fact that competition occurs is shown by a simple example: a US patent search for different combinations of PDE or PDE5 or phosphodiesterase and erectile or dysfunction in patent claims yields 76 patents assigned to 18 different companies and 2 universities [39].

Little is known about how gene patents are being used and whether they are having a net beneficial or detrimental effect on scientific research and commercial product development. Patents are clearly seen as a necessary stimulus for the infusion of venture and risk capital in the biotechnology industry; the role patents play in motivating academic researchers is less clear. Some data have been generated about the licensing of biotechnology patents. These studies suggest that most genetic inventions are not patented, but when they are, they are being licensed on exclusive terms [40, 41]. In turn, researchers and firms appear to have developed various strategies to minimize the potential detrimental effects of the patents, including taking licenses when possible, inventing around patent inventions, going offshore, using publicly available resources, litigation and infringement [42]. Nonetheless, much remains unknown about the effects of these practices on basic research and commercial competition.

\section{Conclusion}

In conclusion, we see that 'gene patents' cover a broad range of invention. Each type has its own potential uses and marketable products, and each raises potential problems depending on how the patents are used in the relevant marketplace. Much remains unknown, and indeed, the market is still adapting to these patents. Thus, it is extremely important to continue to study and monitor how gene patents are being used, licensed and enforced in order to develop policy interventions if deemed necessary.

\section{Acknowledgments}

This paper is a substantially modified version of Merz JF: Disease gene patents; in Fuchs J, Podda M (eds): Encyclopedia of Medical Genomics and Proteomics. New York, Dekker, 2004. Support for underlying research for this article has been provided by the Ethical, Social and Legal Issues Program of the National Human Genome Research Institute of the US National Institutes of Health (HG02034). Thanks are extended to the many colleagues and collaborators who have worked with us on the various studies cited, especially Debra Leonard and Michelle Henry, and thanks to Michelle Henry and Tony Holtzman for comments on previous drafts of this paper.

\section{References}

1 Bar-Shalom A, Cook-Deegan R: Patents and innovation in cancer therapies: lessons from CellPro. Milbank Q 2002;80:637-676.

2 Amgen, Inc, versus Hoechst Marion Roussel, Inc, 314 F 3d 1313 (CAFC 2003).

$\checkmark 3$ Merges RP, Nelson RR: On the complex economics of patent scope. Columbia Law Rev 1990;90:839-916.

$\checkmark 4$ Merz JF: Disease gene patents: overcoming unethical constraints on clinical laboratory medicine. Clin Chem 1999;45:324-330.

5 http://www.cptech.org/ip/health/cl.

6 US Code Title 35, § 203 (1999).
766 Federal Register 1092-1099, January 5, 2001.

8 Berkowitz A, Kevles DJ: Patenting human genes; in Magnus D, Caplan A, McGee G (eds): Who Owns Life? Amherst, Prometheus, 2002, pp 75-98.

$>9$ Katzman S: What is patent-worthy? Due to differing legal standards for patentability, applications for gene patents face different outcomes in various countries. EMBO Rep 2001; 2:88-90.
10 Merz JF, Cho MK, Robertson MA, Leonard DGB: Disease gene patenting is a bad innovation. J Mol Diagn 1997;2:299-304.

11 Merz JF, Cho MK: Disease genes are not patentable: a rebuttal of McGee. Camb Q Healthc Ethics 1998; 7:425-428.

12 US Patent Nos 5,981,178, 5,407,796 and 5,776,677.

13 US Patent Nos 5,306,616 and 6,001,576.

14 US Patent Nos 6,083,698, 5,912,127, $5,756,294,5,753,441,5,750,400,5,709,999$, $5,654,155,6,083,698,5,622,829,6,033,857$. $6,124,104$ and $6,492,109$. 
15 US Patent No 5,508,167.

16 US Patent No 6,027,896.

17 US Patent No 5,935,781.

18 US Patent No 5,945,289.

19 Heller MA, Eisenberg RS: Can patents deter innovation? The anticommons in biomedical research. Science 1998;280:698-701.

20 Cho M: Ethical and legal issues in the 21st Century: Preparing for the Millennium: Laboratory Medicine in the 21st Century. Orlando, AACC Press, 1998, pp 47-53.

21 Cho MK, Illangasekare S, Weaver MA, Leonard DGB, Merz JF: Effects of patents and licenses on the provision of clinical genetic testing services. J Mol Diagn 2003;5:3-8.

22 Merz JF, Kriss AG, Leonard DGB, Cho MK Diagnostic testing fails the test: the pitfalls of patenting are illustrated by the case of haemochromatosis. Nature 2002;415:577-579.

23 Nicol D: Balancing innovation and access to healthcare through the patent system - An Australian perspective. Community Genet 2005; 8:228-234.
24 USPatent Nos 5,851,762,5,612,179,5,192,659 and 5,096,557 are being enforced by Genetic Technologies, Ltd, which acquired the patents from GeneType, AG. http://www.gtg.com.au.

25 Dorozynski A: France challenges patent for genetic screening of breast cancer. BMJ 2001; 323:589.

26 Gold R, Caulfield TA, Ray PN: Gene patents and the standard of care. CMAJ 2002;167: 256-257.

27 Parthasarathy S: The patent is political: the consequences of patenting the BRCA genes in Britain. Community Genet 2005;8:235-246.

28 Merz JF: Discoveries: are there limits on what may be patented? In Magnus D, Caplan A, McGee G (eds): Who Owns Life? Amherst, Prometheus, 2002, pp 99-116.

29 Leonard DGB: Medical practice and gene patents: a personal perspective. Acad Med 2002; 77:1388-1391.

30 http://www.bio.org/speeches/pubs/er/approveddrugs.asp.

31 http://www.bio.org/speeches/pubs/er/statistics.asp.

32 University of Rochester versus G D Searle, Inc, 249 F Supp 2d 216-236 (WDNY 2003).
33 US Patent No 6,410,516

34 Aoki N: Patenting biological pathways; Ariad suit raises questions on laying claim to processes in treating disease. Boston Globe, July 24 , 2002, p C4.

35 US Patent No 6,469,012.

36 Hensley S: Pfizer wins Viagra patent, moves to block competition. Wall Street J, October 23 , 2002.

37 Caulfield T, Gold ER, Cho MK: Patenting human genetic material: refocusing the debate. Nat Rev Genet 2000;1:227-231.

38 Madey versus Duke University, 307 F 3d 1351 (Fed Cir 2002).

$39 \mathrm{http}: / /$ www.uspto.gov/patft/index.html.

40 Henry MR, Cho MK, Weaver MA, Merz JF : DNA patenting and licensing. Science 2002; 297:1279.

41 Henry MR, Cho MK, Weaver MA, Merz JF: A pilot survey on the licensing of DNA inventions. J Law Med Ethics 2003;31:442-449.

42 Walsh JP, Cohen WM, Arora A: Science and the law; working through the patent problem. Science 2003;299:1021. 